Avaiable online at www.babglajol.info

Bangladesh J. Sci. Ind. Res. 43(2),207-214, 2008
BANGLADESH JOURNAL OF SCIENTIFIC AND INDUSTRIAL RESEARCH

E-mail: bjsir07gmail.com

\title{
Effect of Incorporation Time of Groundnut Residue on Succeeding Rice Crop
}

\author{
N. C. Basak,a* S. M. Altaf Hossain,b N. Islamb and N. I. Bhuiyanc \\ aOn-Farm Research Division, Bangladesh Agricultural Research Institute, Mymen- \\ singh-2200, bDept. of Agronomy, Bangladesh Agril. University, Mymensingh and \\ ${ }^{\mathrm{c} B a n g l a d e s h}$ Rice Research Institute, Joydebpur, Gazipur, Bangladesh.
}

\begin{abstract}
An experiment was conducted during 1999 and 2000 kharif seasons to know the right time of incorporation of groundnut crop residue and its subsequent effect on the following rice crop. The treatments of the experiment were five incorporation time of groundnut crop residue i.e., 12 days before transplanting (12 DBT), 9 DBT, 6 DBT, 3 DBT and 0 DBT of following T. aus rice along with a control (no incorporation of residue). The results showed that yield contributing characters and yield of T. aus rice varied significantly and increased with the increase of incorporation time. But incorporation at 3 days before transplanting performed worst due to seedling mortality by gas injury. The other incorporation time treatments gave identical grain yield (3.69-3.99 $\mathrm{t} \mathrm{ha}^{-1}$ in1999 and 3.90-4.10 $\mathrm{t} \mathrm{ha}^{-1}$ in 2000) and straw yield (3.89-4.67 t ha ${ }^{-1}$ in 1999 and 4.00-4.43 $\mathrm{t} \mathrm{ha}^{-1}$ in 2000). The average highest grain yield $\left(4.04 \mathrm{t} \mathrm{ha}^{-1}\right)$ was obtained from the treatment 12 DBT.
\end{abstract}

Key words: Residue effect, Incorporation period, Rice, Yield, Soil fertility•

\section{Introduction}

Bangladesh crop culture is rice-based systems. It has been observed in recent years that the productivity of the systems is declining and that the long term sustainability of these rice-based systems is at a risk (Cassman and Pingali 1995; Fujisaka et al. 1994). In order to overcome these negative trends, fundamental changes in cropping and soil fertility management practices are thought to get more attention of the researchers, planners, policy makers and farming community (Basak 2002). One of the factors responsible for declining productivity is the gradual depletion of organic matter of the soil. The use of green manures for increasing soil productivity and as a source

* Corresponding author 
of nitrogen has been recognized from time immemorial in rice growing countries, particularly in China, India and Japan (Bin 1983; Singh 1984; Watanabe 1984). Legumes, particularly green manure producing legumes have been traditional nitrogen sources in rice-based cropping systems in Asia (Watanabe and Liu 1992). The positive effects of these legumes on rice yields have been well documented. But the use of green manure producing legumes is declining globally (Becker et al. 1995). However, grain legume would be an important crop in tropical rice lowlands (George et al. 1995). Groundnut (Arachis hypogaea L.) is an important grain legume crop in Bangladesh. Its residue can be used in the following rice crops to improve organic matter status and soil fertility and help reduce the use of chemical fertilizers particularly $\mathrm{N}$ for the succeeding rice crops (Basak 2002). An investigation by Toomsan et al. (1995) in Thailand showed that by incorporating crop residues of groundnut, a net contribution of 13 to 100 $\mathrm{kg} \mathrm{N} \mathrm{ha}{ }^{-1}$ was achieved. But the actual decomposition time for groundnut crop residue is unknown. Beri and Meelu (1981) reported that yield from green manure incorporated 1 day before transplanting exceeded yield from green manure incorporated 1 or 2 weeks before transplanting.

In view of the above situations, the present investigation was undertaken to find out the right time of incorporation of groundnut crop residue and its effect on succeeding rice crop in our local climatic condition.

\section{Materials and Methods}

The experiment was conducted at the Jute Research Regional Station, Kishoreganj during kharif 11 season of 1999 and 2000. The soil of the experimental field was silty loam in texture under Old Brahmaputra Floodplain (AEZ 9). Other information about the soil of experimental plot was given in Table I. The design of the experiment was randomized complete block with three replications. Unit plot size was $3 \mathrm{~m} \times 4 \mathrm{~m}$.

Table I. Soil characteristics of the experimental site

\begin{tabular}{l|c}
\hline Parameter & Soil test value \\
\hline Texture & Silty loam \\
$\mathrm{pH}$ & 6.56 \\
Organic matter (\%) & 1.42 \\
Total nitrogen (\%) & 0.084 \\
Available phosphorus (ppm) & 24.0 \\
Available potassium (ppm) & 44.0 \\
Available sulphur (ppm) & 11.0 \\
Available zinc (ppm & 0.27 \\
\hline
\end{tabular}

Five incorporation time of groundnut crop residue along with a control (no residue incorporation) were tested on $\mathrm{T}$. aus rice crop. The treatments of the experiment were as follows:

1. Incorporation of groundnut crop residue 12 days before transplanting (12 DBT)

2. Incorporation of groundnut crop residue 9 days before transplanting (9 DBT) 
3. Incorporation of groundnut crop residue 6 days before transplanting (6 DBT)

4. Incorporation of groundnut crop residue 3 days before transplanting (3 DBT)

5. Incorporation of groundnut crop residue 0 day before transplanting (0 DBT)

6. Control (no residue incorporation)

Green crop residues of groundnut (cv. Jhingabadam) were incorporated into the soil before transplanting of $\mathrm{T}$. aus rice $\left(\mathrm{cv} . \mathrm{BR}_{26}\right)$ @ $31.0 \mathrm{t} \mathrm{ha}^{-1}$. Groundnut crop residues were chopped into small pieces and spreaded on the individual plots. The residues were incorporated into the soil by spade and foot pressing. Fertilizers were applied at the rate of 6020-33-10-4 kg N P K S and Zn/ha in the form of urea, triple super phosphate, muriate of potash, gypsum and zinc sulphate, respectively (BRRI 1997). All the fertilizers were applied as basal except $\mathrm{N}$ fertilizer. Nitrogen (as urea) was top dressed in three equal splits at seedling, tillering and panicle initiation stage. Rice seedlings of 30 days old were transplanted at spacing $20 \mathrm{~cm} \times 15 \mathrm{~cm}$. Intercultural operations were done as and when necessary. Rice seedlings were transplanted during 23 May 1999 and 22 May 2000 and harvesting was done on different dates based on maturity of the crops in different treatments. The treatments of 12 DBT, 9DBT and 6 DBT were harvested during 8687 days after transplanting and 3 DBT was harvested during 88-89 days after transplant- ing. The control plot were harvested during 82-85 days after transplanting. Yield data were collected from an area of $1 \mathrm{~m} \times 3 \mathrm{~m}$. For yield contributing characters, ten plants were collected randomly from each plot. The collected data were analyzed statistically and mean differences were adjudged by DMRT following Gomez and Gomez (1994).

\section{Results and Discussion}

The results of the experiment have been presented in Table I and II. Table I shows the effect of incorporation time on yield contributing characters and Table 2 shows the effect of incorporation time on rice grain and straw yield.

\section{Plant height}

Plant height was the highest when groundnut residue incorporation time was 12 days before transplanting (12 DBT) which gradually decreased with shorter period except in 3 DBT. In 3 DBT many hills were damaged entirely but the remaining hills produced enough tillers. On the contrary the survived hills obtained enough nutrients and produced vigorous tall plants (95.1-97.1 cm). However, the shortest plants were $94.1 \mathrm{~cm}$ in 1999 and $80.0 \mathrm{~cm}$ in 2000 with average plant height of $87.05 \mathrm{~cm}$ in the control treatment. Schulz et al. (1999) observed substantial effect to plant height of rice which was positively related to nitrogen availability from the leguminous residues. 
Table II. Effect of yield contributing characters of T. aus rice

\begin{tabular}{l|c|c|c|c|c|c|c|c|c}
\hline \multirow{2}{*}{ Treatment } & \multicolumn{3}{|c|}{ Plant height $(\mathrm{cm})$} & \multicolumn{3}{c|}{ No. of hills m-2 } & \multicolumn{3}{c}{ No. of tillers hill ${ }^{-1}$} \\
\cline { 2 - 10 } & 1999 & 2000 & Mean & 1999 & 2000 & Mean & 1999 & 2000 & Mean \\
\hline 12 DBT & 99.20 & $91.00 \mathrm{a}$ & 95.10 & $33.20 \mathrm{a}$ & $34.00 \mathrm{a}$ & 33.60 & $10.73 \mathrm{a}$ & 9.87 & 10.30 \\
9 DBT & 98.40 & $90.90 \mathrm{a}$ & 94.65 & $33.00 \mathrm{a}$ & $33.00 \mathrm{a}$ & 33.00 & $10.63 \mathrm{a}$ & 10.00 & 10.31 \\
6 DBT & 98.00 & $90.70 \mathrm{a}$ & 94.35 & $32.33 \mathrm{a}$ & $32.50 \mathrm{a}$ & 32.41 & $10.57 \mathrm{a}$ & 10.73 & 10.65 \\
3 DBT & 101.10 & $93.10 \mathrm{a}$ & 97.10 & $20.20 \mathrm{~b}$ & $22.00 \mathrm{~b}$ & 21.10 & $10.90 \mathrm{a}$ & 10.80 & 10.85 \\
0 DBT & 97.60 & $90.90 \mathrm{a}$ & 94.25 & $29.87 \mathrm{a}$ & $31.50 \mathrm{a}$ & 30.68 & $10.57 \mathrm{a}$ & 10.37 & 10.47 \\
Control & 94.10 & $80.00 \mathrm{~b}$ & 87.05 & $33.30 \mathrm{a}$ & $34.50 \mathrm{a}$ & 33.90 & $8.20 \mathrm{~b}$ & 8.03 & 8.11 \\
\hline F-test & $\mathrm{ns}$ & $* *$ & - & $* *$ & $* *$ & - & $* *$ & $\mathrm{~ns}$ & - \\
CV (\%) & 2.77 & 1.96 & - & 4.30 & 3.84 & - & 4.68 & 11.95 & - \\
\hline
\end{tabular}

Figures in a column followed by dissimilar letters differed significantly as per DMRT.

**: Significant at $1 \%$ level

ns: Non- significant.

Table 11. Continued...............

\begin{tabular}{l|c|c|c|c|c|c}
\hline \multirow{2}{*}{ Treatment } & \multicolumn{3}{|c|}{ No. of grains paniclel ${ }^{-1}$} & \multicolumn{3}{|c}{ 1000-grain weight (g) } \\
\cline { 2 - 7 } & 1999 & 2000 & Mean & 1999 & 2000 & Mean \\
\hline 12 DBT & $95.60 \mathrm{a}$ & $84.20 \mathrm{ab}$ & 89.90 & $24.60 \mathrm{ab}$ & $25.90 \mathrm{a}$ & 25.25 \\
$9 \mathrm{DBT}$ & $100.50 \mathrm{a}$ & $84.30 \mathrm{ab}$ & 92.40 & $24.73 \mathrm{ab}$ & $25.73 \mathrm{a}$ & 25.23 \\
$6 \mathrm{DBT}$ & $102.20 \mathrm{a}$ & $80.40 \mathrm{~b}$ & 91.30 & $24.87 \mathrm{a}$ & $25.60 \mathrm{a}$ & 25.23 \\
$3 \mathrm{DBT}$ & $103.00 \mathrm{a}$ & $101.10 \mathrm{a}$ & 102.05 & $24.07 \mathrm{bc}$ & $24.93 \mathrm{ab}$ & 24.50 \\
$0 \mathrm{DBT}$ & $95.90 \mathrm{a}$ & $90.80 \mathrm{a}$ & 93.35 & $25.07 \mathrm{a}$ & $25.67 \mathrm{a}$ & 25.37 \\
Control & $78.50 \mathrm{~b}$ & $63.40 \mathrm{c}$ & 70.95 & $23.60 \mathrm{c}$ & $24.33 \mathrm{~b}$ & 23.96 \\
\hline F-test & $* *$ & $* *$ & - & $* *$ & $* *$ & - \\
CV(\%) & 9.09 & 9.69 & - & 1.03 & 1.68 & - \\
\hline
\end{tabular}

Figures in a column followed by dissimilar letters differed significantly as per DMRT.

**: Significant at $1 \%$ level

\section{Number of hills $\mathbf{m}^{-2}$}

Number of hills $\mathrm{m}^{-2}$ was observed to be the highest 33.30 hills $\mathrm{m}^{-2}$ in1999 and 34.50 hills $\mathrm{m}^{-2}$ in 2000 with average number of 33.90 hills $\mathrm{m}^{-2}$ in the control treatment which was statistically identical with other treatments except 3 DBT. In 3 DBT the average number of hills $\mathrm{m}^{-2}$ was 21.10 .

After transplanting many seedlings even the entire hills in many rows in the 3 DBT treat- 
ment were damaged which ultimately affected the yield. This might be due production of harmful gases. In the earlier incorporation time and even in the 0 DBT this problem was not observed. This indicated that groundnut residue incorporation at 6-12 days before transplanting of rice seedling overcame the problem of gas injury period. In 0 DBT treatment the seedlings received no gases during transplanting and the seedlings established within 3 days after transplanting and after this period the seedlings were not damaged. In the control treatment the problem of seedling mortality was not observed at all. Due to this reason, number of hills per unit area were lower in 3 DBT and higher in other treatments. A number of earlier workers reported that anaerobic decomposition of organic residues produced volatile fatty acids and phenolics (Pareek, 1976; Tsutsuki, 1983; Lynch, 1977). Gotoh and Onikura (1971) reported that in wormer period straw decomposes rapidly and the acids disappear quickly. In Bangladesh the temperature is very high in the month of May which helped to decompose the groundnut residues earlier. In 3 DBT the gases accumulation was probably high and in other incorporation time the gases might mostly disappeared causing no or less seedling damage.

\section{Number of tillers hill ${ }^{-1}$}

The highest average number of tillers hill ${ }^{-1}$ (10.85) was observed in 3 DBT which was more or less same with all other treatments except the control (no incorporation of residue). The control treatment produced significantly the lowest (8.20) tillers hill-1 in 1999 and 8.03 tillers hill $^{-1}$ in 2000. The higher number of tillers hill-1 in 3 DBT might be due to less number of total hills in the plots of this treatment which helped to receive more nutrient to the tillers of the remaining hills. Like plant height, Schulz et al. (1999) also observed substantial effect to number of rice panicles per unit area which was positively related to nitrogen availability from the leguminous residues.

\section{Number of grains panicle ${ }^{-1}$}

Number of grains panicle ${ }^{-1}$ was significant in both the years. Number of grains panicle ${ }^{-1}$ were higher in the residue incorporated plots (95.6-103.0 in 1999 and 80.4-101.1 in 2000). The average higher number of grains panicle-1 (102.05) were obtained from the 3 DBT treatment whereas the lowest (70.95) was in the control treatment. In 3 DBT treatment number of tillers per unit area were lower than the other treatments which helped to get better nourishment of the crop and thus the development of grains in this treatment was better. The results of two years data showed that the number of grains panicle-1 followed no regular trend.

\section{Thousand grain weight}

Thousand grain weight varied significantly in both the years. Like number of grains pan- 
icle $^{-1}$, the 1000-grain weight also showed no regular trend. However, the highest 1000grain weight (25.90 g ) was found in 12 DBT treatment in 2000 followed by $25.07 \mathrm{~g}$ in $0 \mathrm{DBT}$ in 1999. However, the average 1000-grain weight in different incorporation time treatments varied from 24.50 - $25.37 \mathrm{~g}$ and the two years mean lowest 1000 grain weight $23.96 \mathrm{~g}$ was obtained from the control treatment. among the residue incorporated plots. The highest (3.99 t ha-1 in 1999 and $4.10 \mathrm{t} \mathrm{ha}^{-1}$ in 2000) grain yield was observed in 12 DBT. Bhardwaj (1982) showed that maximum rice yield was obtained when rice was transplanted almost immediately after incorporation of green manure crop. Increasing the time for decomposition resulted in significant yield losses. The control treatment had the lowest (2.81 t ha ${ }^{-1}$ in 1999 and $2.74 \mathrm{t} \mathrm{ha}^{-1}$ in 2000)

Table III. Performance of grain and straw yields of T. aus rice

\begin{tabular}{l|c|c|c|c|c|c}
\hline \multirow{2}{*}{ Treatment } & \multicolumn{3}{|c|}{ Grain yield (t/ha) } & \multicolumn{3}{|c}{ Straw yield (t/ha) } \\
\cline { 2 - 7 } & 1999 & 2000 & Mean & 1999 & 2000 & Mean \\
\hline $12 \mathrm{DBT}$ & $3.99 \mathrm{a}$ & $4.10 \mathrm{a}$ & 4.04 & $4.67 \mathrm{a}$ & $4.43 \mathrm{a}$ & 4.55 \\
$9 \mathrm{DBT}$ & $3.90 \mathrm{a}$ & $4.09 \mathrm{a}$ & 3.99 & $4.11 \mathrm{ab}$ & $4.35 \mathrm{a}$ & 4.23 \\
$6 \mathrm{DBT}$ & $3.97 \mathrm{a}$ & $4.00 \mathrm{a}$ & 3.98 & $4.00 \mathrm{ab}$ & $4.13 \mathrm{a}$ & 4.06 \\
$3 \mathrm{DBT}$ & $2.95 \mathrm{~b}$ & $3.00 \mathrm{~b}$ & 2.97 & $3.50 \mathrm{~b}$ & $3.31 \mathrm{ab}$ & 3.40 \\
$0 \mathrm{DBT}$ & $3.69 \mathrm{a}$ & $3.90 \mathrm{a}$ & 3.79 & $3.89 \mathrm{~b}$ & $4.00 \mathrm{ab}$ & 3.94 \\
Control & $2.81 \mathrm{~b}$ & $2.74 \mathrm{~b}$ & 2.77 & $2.97 \mathrm{c}$ & $3.00 \mathrm{~b}$ & 2.98 \\
\hline F-test & $* *$ & $* *$ & - & $* *$ & $* *$ & - \\
CV (\%) & 8.07 & 9.53 & - & 6.74 & 10.47 & - \\
\hline
\end{tabular}

Figures in a column followed by dissimilar letters differed significantly as per DMRT.

**: Significant at $1 \%$ level

\section{Grain yield}

Grain yield increased with the increase of incorporation time in both the years with the exception of 3 DBT treatment. Except 3 DBT other incorporation time treatments gave the identical yields of 3.69-3.99 $\mathrm{t} \mathrm{ha}^{-1}$ in 1999 and 3.90-4.10 $\mathrm{t} \mathrm{ha}^{-1}$ in 2000. Due to seedling mortality in 3 DBT treatment the grain yield in this treatment was the lowest (2.95 t ha-1 in 1999 and $3.00 \mathrm{t} \mathrm{ha}^{-1}$ in 2000) grain yield among all the treatments. The lower yield in control treatments clearly indicates the benefit of groundnut residue incorporation. An increased grain yield of rice due to organic residue incorporation was reported by More (1994).

\section{Straw yield}

Significant variation in straw yield was observed in different treatments in both the 
years. Like grain yield, straw yield was also increased with the increase of incorporation time with exception in case of 3 DBT treatment where plant population unit ${ }^{-1}$ area was less as many seedlings were died after transplantation might be formation of gaseous product and its injury to rice seedlings. The highest straw yield (4.67 t ha-1 in 1999 and $4.43 \mathrm{t} \mathrm{ha}^{-1}$ in 2000) was observed in 12 DBT treatment which was statistically identical with 9 DBT and 6 DBT in both the years. Out of the different incorporation period 3 DBT gave the lower straw yield (3.50 $\mathrm{t} \mathrm{ha}^{-1}$ in 1999 and $3.31 \mathrm{t} \mathrm{ha}^{-1}$ in 2000) in both the years. The control treatment gave lowest straw yield of $2.97 \mathrm{t} \mathrm{ha}^{-1}$ in 1999 and $3.00 \mathrm{t}$ $\mathrm{ha}^{-1}$ in 2000 with average lowest straw yield of $2.98 \mathrm{t} \mathrm{ha}^{-1}$. The lower straw yield in control treatment might be attributed due to lower plant height and less number of tillers hill $^{-1}$. The higher straw yields in the groundnut residue incorporated plots might be contribution of the residues over no residue incorporation. An increase in straw yield due to straw/residue incorporation was also reported by Rajput and Warsi (1992).

\section{Conclusion}

The results show that groundnut residue should be incorporated at least 6-12 days before transplanting of rice seedling for decomposition which would help easy establishment and nourishment of following rice crop seedlings. However, for better yield it could be recommended that groundnut crop residues should be incorporated 12 days before transplanting of rice seedlings.

\section{References}

Basak, N.C. (2002) Effects of groundnut crop residue and chemical fertilizers on the productivity of Groundnut-rice-rice pattern. Ph. D Thesis, Dept. Agron. Bangladesh Agril. Univ, Mymensingh, Bangladesh. 216p.

Becker, M. Ladha, J.K. Ali, M. (1995) Green manure technology: potential, usage and limitations. A case study for lowland rice. Plant Soil. 174: 181-194.

Beri, V. and Meelu, O.P. (1981). Substitution of nitrogen through green manure in rice. Indian Fmg. 31 (2): 3-4.

Bhardwaj, K.K.R. (1982) Effect of the age and decomposition period of dhaincha on the yield of rice. Indian J. Agron. 27: 284-285.

Bin, J. (1983) Utilization of green manure for raising soil fertility in China. Soil Sci. 135: 65-69.

BRRI (Bangladesh Rice Research Institute). (1997) Adhunik Dhaner Chas. Bangladesh Rice Res. Inst., Joydebpur, Gazipur. pp.3438 (In Bangla).

Cassman, K.G. Pingali, P.L. (1995) Extrapolating trends from long-term experiments to farmers fields: The case of irrigated rice systems in Asia. In: V. Barnett, R. Payne and R. Steiner (eds), Agricultural sustainability: Economic, Environmental and Statistical 
Considerations, John Wiley \& Sons Ltd, Chichester, U.K. pp.63-84.

Fujisaka, S. Harrington, L. Hobbs, P. (1994) Rice-Wheat in South Asia: Systems and long-term priorities established through diagnostic research. Agric. Sys. 46: 169187.

George, T. Ladha, J. K. Garrity, D. P. and Torres, R.O. (1995) Nitrogen dynamics of grain legume-weedy fallow-flooded rice sequences in the tropics. Agron. J. 87: 1-6.

Gomez, K.A. and Gomez, A. A. (1994) Statistical procedures for Agricultural Research (3rd edn.), John Wiley \& Sons, New York. 680p.

Gotoh, S. and Onikura, Y. (1971) Organic acids in a flooded soil recieving added rice straw and their effect on the growth of rice. Soil Sci. Plant Nutr. 17 (1): 1-8.

Lynch, J.M. (1977) Phytotoxicity of acetic acid produced in the anaerobic decomposition of wheat straw. J. Appl. Bacteriol. 42: 81-87.

More, S.D. (1994) Effect of farm wastes and organic manures on soil properties, nutrient availability and yield of rice-wheat grown on sodic vertisol. J. Indian Soc. Soil Sci. 42 ( 2): 253-256.

Pareek, R.P. (1976) Phenolic acids in wheat and paddy rhizosphere amended with crop residue. Proc. Indian Acad. Sci. 83B (6): 225-231.

Rajput, A.L. and Warsi, A.S. (1992) Effect of nitrogen and organic manure on rice (Oryza sativa) yield and residual effect effect on wheat (Triticum aestivum) crop. Indian $J$. Agron. 37 (4): 716-720.

Schulz, S. Keatinge, J.D.H. and Wells, G.J. (1999) Productivity and residual effects of legumes in rice-based cropping systems in a warm-temperate environment 11. Residual effects on rice. Field Crops Res. 61: 37-49.

Singh, N.T. (1984) Green manures as sources of nutrients in rice production .In: Organic Matter and Rice. Intl. Rice Res. Inst. P.O. Box 933, Manila, Philippines. pp.217-228.

Toomsan, B. McDonagh, J.F. Limpinuntana, V. Giller, K.E. (1995) Nitrogen fixation by groundnut and soybean and residual nitrogen benefits to rice in farmers' fields in Northeast Thailand. Pl. Soil 175: 45-56.

Tsutsuki, K. (1983) Volatile products and low molecular weight phenolic products of the anaerobic decomposition of organic matter. In: Organic Matter and Rice. Intl. Rice Res. Inst., Los Banos, Philippines. pp. 333-347.

Watanabe, I. (1984) Use of green manures in Northeast Asia. In: Organic Matter and Rice. Intl. Rice Res. Inst. P. O. Box 933, Manila, Philippines, pp. 229-234.

Watanabe, I. Liu, C.C. (1992) Improving nitrogen-fixing systems and integrating them into sustainable rice farming. Plant \& Soil. 141: 57-67.

Received : September 05, 2007;

Accepted : February 03, 2008 